\title{
Bóg jako źródło moralności. Intuicje św. Augustyna w Wyznaniach 7.10-11 w kontekście dyskusji z tradycją starożytną ${ }^{1}$
}

\author{
God as the Source of Morality. St. Augustine's Intuitions in Confessions 7.10-11 \\ in the Context of a Discussion with the Ancient Tradition
}

\author{
MARTYNA KOSZKAŁO \\ Uniwersytet Gdański \\ martyna.koszkalo@ug.edu.pl, ORCID: 0000-0002-1475-4319
}

\begin{abstract}
Streszczenie: W artykule przedstawiam relacje Boga/bogów wobec moralności zarówno w greckiej religii i filozofii, jak i w poglądach św. Augustyna na podstawie rozróżnień uczynionych przez Johna Hare’a. Twierdzę, że intuicje Augustyna istotnie dopełniają koncepcję Boga jako źródła moralności obecną zarówno w starożytnej tradycji filozoficznej, jak i religijnej. W pierwszej części artykułu ukazuję relację bogów greckiej religii ludowej do moralności i stwierdzam, że bycie gwarantem moralności nie wymagało od nich posiadania wzorcowego charakteru moralnego. Następnie pokazuję, że zmiana tego zjawiska miała miejsce w epoce sokratejskiej. Bóg/bogowie Sokratesa, Platona czy Arystotelesa nabierają cech doskonałościowych i to sankcjonuje ich moc kształtowania moralności. W ramach tych koncepcji zrodziła się idea upodobnienia się do Boga/bogów i naśladowania wzorca charakterologicznego poprzez wykonywanie działań, które wykonuje Bóg (poznawanie, doskonałość moralna). Bóg, zwłaszcza rozumiany filozoficznie, był traktowany również jako cel oraz przedmiot uszczęśliwiający. W ostatniej części artykułu analizuję koncepcję św. Augustyna. Pokazuję, że oprócz tego, że Bóg jest prawodawcą oraz uszczęśliwiającym celem ostatecznym z tego powodu, że stwarza istoty do Niego podobne, jest źródłem moralności nie tylko jako wzorzec charakterologiczny, ale przede wszystkim jako istota stwórcza. Ukazuję, że zło moralne jest odwróceniem się sprawcy od Boga i załamaniem ontologicznego porządku. W artykule przedstawiam możliwe interpretacje wyrażenia regio dissimilitudinis oraz tekstualne źródła tego pojęcia. Ukazuję również te aspekty poglądów Augustyna, które istotnie uzupełniają i przekraczają model neoplatoński w Wyznaniach 7.10-11.
\end{abstract}

Słowa kluczowe: Bóg, źródło moralności, Sokrates, Platon, Arystoteles, św. Augustyn, regio dissimilitudinis, neoplatonizm

Abstract: In this article, I present the relationship between God/gods and morality in both the Greek re-
ligion and philosophy and in the views of St Augustine based on distinctions made by John Hare. I argue
that Augustine's intuitions are indeed complementary to the concept of God as the source of morality
present both in the ancient philosophical and religious traditions. In the first part of the article, I show
the relation of the gods of Greek popular religion to morality. I argue that being guarantors of morality
did not require them to possess exemplary moral character. I then show that a change in this regard took
place in the Socratic era. The God/gods of Socrates, Plato, or Aristotle acquire perfect qualities, which
sanctions their power to shape morality. Within these concepts, the idea was born of becoming God/
god-like and imitating a model of character by performing the actions carried out by God (cognition,

1 Artykuł powstał w ramach Programu Wsparcia Humanistyki Gdańskiej dofinansowanego przez Uniwersytet Gdański. Dziękuję anonimowemu recenzentowi artykułu za bardzo cenne uwagi filologiczne. 
moral perfection). God, especially the philosophical God, was also treated as an end and as a felicific object. In the last part of this article, I analyze the concept of St Augustine. I show that, in addition to being the lawgiver and the ultimate felicific end, because He creates beings like Him, God is the source of morality not only as a model of character but above all as a creative being. I show that in committing moral evil, the perpetrator turns away from God and disrupts the ontological order. I present possible interpretations of the expression region of dissimilarity and the textual sources of this concept. I also show those aspects of Augustine's views that significantly complement and transcend the Neoplatonic model in Confessions 7.10-11.

Keywords: God, the source of morality, Socrates, Plato, Aristotle, St. Augustine, region of dissimilarity, Neoplatonism

Religia i moralność są ze sobą powiązane, gdyż każda religia - oprócz określonego zbioru przekonań na temat Boga/bóstw(a) oraz natury człowieka - zazwyczaj zawiera również zestaw usankcjonowanych norm, które wyznawca powinien respektować ${ }^{2}$ Współczesne debaty metaetyczne, poruszające zagadnienie związku religii i moralności, koncentrują się zazwyczaj na pytaniu, czy odwoływanie się do Boga jako źródła moralności jest najlepszym sposobem uzasadnienia obiektywności faktów moralnych. Zwolennicy tak zwanej etyki Bożych nakazów (Divine Command Ethics) uważają, że moralność wymaga ostatecznie podstaw teistycznych. Z drugiej strony przyjęcie perspektywy teistycznej w uzasadnieniu moralności prowadzi do pytania o to, jakie atrybuty musi posiadać Bóg, aby ową moralność ostatecznie móc sankcjonować. W taki sposób relację Boga do moralności analizuje John Hare³. Przedstawia on cztery odmienne koncepcje Boga: (1) jako tego, który jest przedmiotem pragnienia, (2) jako kogoś, kto kocha, (3) jako suwerena (legislatora) oraz (4) jako wzorca. W ramach tych dystynkcji opisuje odpowiednio stanowiska Arystotelesa, Jana Dunsa Szkota, Immanuela Kanta oraz swojego ojca Richarda M. Hare’a. Korzystając z rozróżnień J. Hare’a, w artykule odniosę się do refleksji nad relacją Boga do moralności obecnych w różnych greckich koncepcjach filozoficznych oraz w greckiej religii. Na tym tle przedstawię niektóre rozważania poświęcone tej relacji przez św. Augustyna w Wyznaniach. Jego intuicje istotnie dopełniają koncepcję Boga jako źródła moralności obecną w starożytnej tradycji filozoficznej i religijnej.

\section{Bogowie religii greckiej a moralność}

W greckich mitach obecność aspektu etycznego jest oczywista. Wiele mitycznych opowieści pełni funkcję pedagogiczną - z pochwałą cnotliwego życia związane jest jednocześnie ostrzeżenie przed nadmierną dumą. Bogowie ukazani są często jako

Zob. socjologiczno-kulturowe określenie religii w: Herbut, „Religia”, 466.

Hare, God and Morality, 3. 
ci, którzy wymierzają człowiekowi karę za pychę (üßpıৎ), a dzięki mitom człowiek rozpoznaje swoje miejsce w świecie oraz swą egzystencjalną sytuację. Pragnienie nadmiaru czy chełpliwa pycha rodzą w człowieku pragnienie dorównania bogom, przed czym przestrzegają historie Arachne, Niobe czy Ajaksa, ukazujące zgubne konsekwencje takich postaw.

Bogowie w greckich wyobrażeniach religijnych są zatem strażnikami pewnego kosmicznego etycznego ładu, któremu człowiek winien się podporządkować. Czy ład obowiązuje ze względu na szczególne właściwości bogów? Wydaje się, że nie muszą oni posiadać szczególnych własności moralnych, aby ów ład sankcjonować. Człowiek powinien po prostu zaakceptować swoje miejsce w hierarchii bytów, niezależnie od tego, jacy są sami bogowie. Jednak w greckiej kulturze spojrzenie na moralny charakter bogów podlegało pewnej ewolucji - szczególnie, co podkreśla Jon D. Mikalson, jeśli weźmie się pod uwagę odmienność trzech koncepcji bogów: bogów greckich filozofów, bogów greckich poetów oraz bogów kultu (theologia fabularis, theologia civilis). Takie cechy, jak mądrość czy sprawiedliwość, w ogóle nie musiały przysługiwać bogom kultu. Poeci z kolei mogli zarówno przypisywać im owe cechy, jak i je zdecydowanie odrzucaćt. W klasycznym obrazie poetyckiej mitologii bogowie działali częstokroć w sposób moralnie wątpliwy, walcząc o dominację czy wchodząc w spory. Zwraca się jednak uwagę, że zachowują się podobnie do królów, którzy z racji przynależności do swojej klasy nie przekraczają pewnych granic moralnych. Jak pisze Mircea Eliade, „jak mykeńscy królowie, bogowie także potrafią być kapryśni i okrutni, jednakże nigdy się nie zniżają do podłości”' Związek bóstwa i moralności obecny jest w dziełach Homera. Homerycki obraz Zeusa to obraz gwaranta sprawiedliwości - jest on opiekunem praw i cudzoziemców oraz obrońcą błagających. Sprawiedliwość w tym wypadku miałaby niebiańskie źródła - Zeus jest dawcą $\delta$ ín dla sprawujących władzę, gdyż dał królom berło i obyczaje $(\theta \dot{\varepsilon} \mu \tau \tau \varepsilon \varsigma)^{6}$. W Iliadzie (XVI.385) pojawia się również przekonanie, że gdy ludzie dopuszczają się niesprawiedliwości, Zeus wymierza karę, zsyłając ulewę w czasie żniw. Nie tylko zatem jest on źródłem sprawiedliwości, ale i najwyższym sędzią. Należy również zaznaczyć, że wizerunek bogów w Odysei zmienia się w stosunku do obrazu z Iliady. Jak zauważa Alfred Heubeck, bogowie Iliady aktywnie uczestniczą w życiu śmiertelników, czy to ich chroniąc, czy to im pomagając, a jednocześnie miotają nimi takie same gwałtowne uczucia i emocje jak ludźmi. Z kolei w Odysei działania bogów są podporządkowane działaniu Zeusa, który wie, jak we właściwy sposób wszystkim kierować. Zeus nie ulega już bezrozumnym impulsom i emocjom, ale kieruje się mądrością, rządząc przeznaczeniem w świecie zgodnie z zasadami moralnymi ${ }^{7}$.

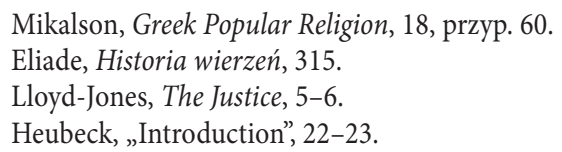


Konieczność związania natury bóstwa $\mathrm{z}$ atrybutem dobroci w swoich tragediach mocno podkreśla Eurypides: „To ci chcę powiedzieć: bogowie-sprawcy zła to nie bogowie"s, ale jest to już autor epoki sokratejskiej.

Według Mikalsona przekonanie, że jeden lub wszyscy bogowie są mądrzy i sprawiedliwi, zostało w pełni wypracowane dopiero $\mathrm{w}$ tradycji sokratejskiej i stało się powszechnie akceptowane w filozoficznej koncepcji bogów 9 . Odnosząc się do rozróżnień poczynionych przez J. Hare’a, model relacji bogów do moralności w greckiej mitologii i poezji można określić mianem deontologicznego, bowiem grecki bóg może być prawodawcą, ale nie jest on ostatecznie ani przedmiotem pragnienia, ani kimś, kto kocha, ani wzorcem charakterologicznym.

\section{Bóg greckiej filozofii a moralność}

Popularna i raczej powierzchowna interpretacja filozofii Milezyjczyków jako czystej filozofii przyrody, w której następuje odczarowanie świata na rzecz wizji naukowej, jest nie do utrzymania. Klasycznym autorem, który interpretował filozofię presokratejską jako teologię, był Werner Jaeger. Nawet filozofię Anaksymandra opisuje on jako pierwszą filozoficzną teodyceę ze względu na boski wymiar sprawiedliwości normy, która jest wewnętrzną zasadą całej rzeczywistości. Owa norma jest wyrażona między innymi w słynnym fragmencie przytoczonym przez Simplicjusza „[rzeczy] ponoszą bowiem nawzajem karę sprawiedliwą za niesprawiedliwość swoją w po-

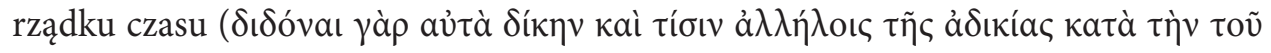

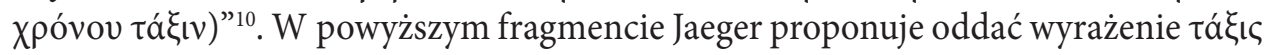
jako „postanowienie”, a nie „porządek” - wówczas zmiany dokonujące się w przyrodzie podlegają boskiej sprawiedliwości, która jest w jakimś sensie ustanawiana ${ }^{11}$. Zastępuje on zatem wyrażenie dotyczące faktów wyrażeniem $z$ dziedziny prawa i moralności. W swej najnowszej pracy, opracowując ten wątek myśli Anaksymandra, Ryszard Legutko używa nawet wyrażenia „swoista decyzja” w odniesieniu do kontrolującego świat działania apeironu. W swojej interpretacji odmawia apeironowi istnienia osobowego, ale zaznacza, że stosowane przez Anaksymandra pojęcie „boskości” sugeruje, że przedstawienie działania tej prazasady nie jest jedynie opisem uporządkowanego i sprawiedliwego następstwa zmian w świecie przyrody, ale opisem działania w pewnym sensie moralnego sprawcy $^{12}$. $Z$ kolei Jaeger przypisuje

Euripides, Bellerophon 292 (Łanowski, 657).

Mikalson, Greek Popular Religion, 18, przyp. 60.

10 Diels-Kranz, 12 B 1, za: Reale, Historia, 85. Tłumaczenie przypisane K. Leśniakowi (zob. ibidem, przyp. 7), zgodne z rozumieniem, które nadał mu Hermann Diels.

11 Jaeger, Teologia, 78-79.

12 Legutko, Filozofia presokratyków, 53. 
również prazasadzie Anaksymenesa cechy, które zazwyczaj przynależą do bytu osobowego. Kiedy Anaksymenes ożywia apeiron, utożsamiając go z powietrzem, nie ma na myśli jedynie fizjologicznej zasady życia, ale boską zasadę, czyli zasadę umysłową, która dzięki tej swojej własności może nad wszystkim panować ${ }^{13}$.

Jeśli zgodzimy się z powyższymi interpretacjami, zauważymy, że już wśród pierwszych filozofów przyrody zachodzi związek między tym, co boskie (prazasada), a w jakiś sposób rozumianą moralnością (sprawiedliwość). Rodząca się stopniowo filozoficzna koncepcja boga coraz bardziej oddalała jego obraz od ludzkich wyobrażeń i antropomorfizacji. Według Jaegera Ksenofanes wiąże swoją nową filozoficzną koncepcję boga, który nie może posiadać żadnych ludzkich słabości i niedoskonałości, z pojęciem porządku społecznego. Można się w tym również doszukiwać idei boga jako źródła moralności. Bogowie religii greckiej byli silnie związani z życiem społecznym w polis, a religia stawała się polityczną teologią - i taką samą rolę Ksenofanes przypisywał bogu filozoficznemu ${ }^{14}$. W filozofii Heraklita mamy z kolei do czynienia zarówno z krytyką pewnych aspektów religii ludowej, jak i z podkreśleniem, że bóg jest doskonałością, dlatego „Jedno, jedyne mądre, chce i nie chce być nazwane imieniem Zeusa" ${ }^{15}$. Niezależnie zatem od tego, czy bóg filozofów miał cechy osobowe, czy nie, z pewnością nabierał cech doskonałościowych. Taki bóg, jeśli miał być źródłem moralności, stawał się nim, będąc wzorcem doskonałości lub przedmiotem dążenia.

Narodziny etyki w V wieku przed Chr. budzą pytania o związek boga z moralnością. Tej relacji można doszukać się nawet w filozofii sofistów, choć stanowi to przedmiot sporu. Ilustracją tego są wątki obecne w Wielkiej Mowie wygłoszonej przez Protagorasa. Według niego darami, które ludzie powszechnie otrzymali od Zeusa, były poczucie wstydu i poczucie sprawiedliwości. Oba dary stanowiły fundament organizacji życia społecznego, gwarantowały możliwość utrzymania porządku i miały charakter uniwersalny ${ }^{16}$. Jak owa relacja przedstawia się w poglądach Sokratesa? Biorąc pod uwagę świadectwo Platona, które dał w Apologii, Sokrates postrzegał swoje życie, zwłaszcza życie filozoficzne, jako działalność misyjną. Bóg Apollo poprzez wyrocznię w Delfach trwale wpisał się w motywację podejmowanych przez Sokratesa działań. Warto podkreślić, że relacja Sokratesa do boga (tego, co boskie) ma charakter dwojaki: $z$ jednej strony jest to relacja zewnętrzna, wyrocznia wskazała bowiem na Sokratesa, odpowiadając na pytanie Chairefonta, a z drugiej - wewnętrzna, gdyż Sokrates doświadcza obecności daimoniona - boskiego głosu wewnętrznego. O ile działanie boga wyroczni jest pozytywne - Sokrates, chcąc rozwiązać zagadkę, wie, co

\footnotetext{
Jaeger, Teologia, 80 .

Jaeger, Teologia, 99 .

Jaeger, Teologia, 196-197.

Istnieje dyskusja co do tego, czy poglądy te można faktycznie przypisać Protagorasowi. Zwolenników i przeciwników sporu wymienia Ryszard Legutko (Sokrates, 153, przyp. 61). Wątek religijny obecny w tej mowie skłania badaczy do odrzucenia tezy, że jej autorem mógł być Protagoras.
} 
ma czynić - o tyle działanie głosu wewnętrznego ma charakter negatywny - ostrzega on, gdy Sokrates ma popełnić nieprawość - a jego pozytywne działanie sprowadza się jedynie do aprobującego milczenia w sytuacji, gdy Sokrates postępuje właściwie.

Moralny aspekt działań Sokratesa jest oczywisty. Służba bogu objawiać się miała przede wszystkim w podejmowanym przez Sokratesa wyzwaniu wprowadzenia w Atenach ładu moralnego, związanego z nabywaniem przez obywateli właściwych postaw etycznych, gwarantowanych rozpoznaniem wartości. Bycie roztropnym okazywało się bowiem cechą rzadką i przynależną raczej tym, którzy nie mieli o sobie najlepszej opinii ${ }^{17}$. Misja musi zostać wypełniona, gdyż powinność wobec spraw boskich ma według Sokratesa charakter najwyższy ${ }^{18}$. Sokrates w dyskusji z Meletosem zbija zarzut bezbożności, używając języka religijnego i mówiąc, że troszczy się o sprawy duchowe i o sprawy boskie. Rozwiązanie zagadki, którą formułuje Pytia, mówiąc, że Sokrates jest najmądrzejszym z ludzi, odsłania nie tylko naturę człowieka, ale przede wszystkim naturę boga - naprawdę mądry jest tylko bóg. Bóg Sokratejski nie jest już niedoskonałym bogiem greckiej theologiae fabularis, ale posiada atrybut najwyższej mądrości. Można się zastanawiać, w jaki sposób rozumiał Sokrates ową boską mądrość. Legutko podkreśla, że zarówno wiedza boga, jak i człowieka musi być pod pewnym względem tak samo rozumiana, dlatego skoro wiedza moralna jest warunkiem koniecznym dobrego postępowania, to sprawiedliwy bóg na pewno musi ją posiadać. Oprócz wiedzy moralnej wiedza boga zawierałaby dodatkowo treści dotyczące świata (wiedza kosmologiczno-ontologiczna) ${ }^{19}$. Przy stanowisku intelektualizmu etycznego bóg musi zatem być mądry, gdyż jest sprawiedliwy.

W Eutyfronie Sokrates podejmuje próbę wyjaśnienia natury boskiej służby. Nie może ona polegać na pomaganiu bogom w tym, by stali się lepszymi, niż są, gdyż nie mogą się stać lepszymi ${ }^{20}$. Czy potrzebne są im nasze dary? Wydaje się, że to od nich płyną dary, a bogom nic nie można dodać ${ }^{11}$. Sokrates prowadzi również Eutyfrona do odrzucenia tezy, że pobożność sprowadza się do rytuałów, i w efekcie podkreśla, że zbożne jest to, co bogom miłe ${ }^{22}$. Służba bogom być może sprowadza się do czynienia tego, co bogom miłe, czyli dobra i sprawiedliwości.

Przekonaniu o doskonałościowym charakterze boga Platon daje wyraz w wielu dialogach. W Państwie krytykuje obraz bogów obecny w theologiae fabularis, przestrzegając przed zgubnym wpływem historii o amoralnym zachowaniu się bogów. Sam skłania się do przekonania, że obraz obecny w historiach homeryckich może być alegoryczny, ale nie każdy potrafi to zrozumieć, dlatego takich historii nie należy

17 Plato, Apologia Socratis 22a (Witwicki, 253).

18 Plato, Apologia Socratis 21e (Witwicki, 253).

19 Zob. Legutko, Sokrates, 577.

20 Plato, Euthyphron 13c (Witwicki, 202).

21 Plato, Euthyphron 15a (Witwicki, 205).

22 Plato, Euthyphron 15b (Witwicki, 206). W dialogu nie zostaje rozstrzygnięty dylemat, czy dobre jest coś dlatego, że się bogom podoba, czy podoba się im dlatego, że jest dobre. 
opowiadać w doskonałym państwie ${ }^{23}$. Bóg staje się u Platona wzorcem charakterologicznym - nie tylko jest niezmienny, prawdziwy i nie wprowadza ludzi w błą $\mathrm{d}^{24}$, ale i nie jest zły, ani nie ma w nim żadnej niesprawiedliwości ${ }^{25}$. Dlatego, że jest wzorcem moralnym, może być nazwany źródłem moralności. W Teajtecie Platon prezentuje zasady etyki jako drogę upodobnienia się do tego wzorca. Bóg jest wzorcem sprawiedliwości, a drogą doskonałego życia jest „upodobnienie się do boga, według możności. Upodobnić się do niego to stać się sprawiedliwym i pobożnym przy zachowa-

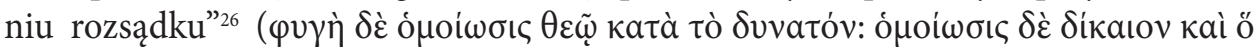

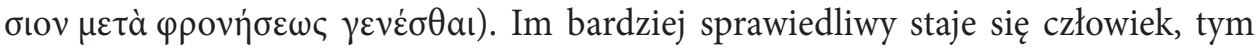
bardziej staje się podobny do boga ${ }^{27}$. W platońskim Teajtecie życie człowieka sprawiedliwego i człowieka niesprawiedliwego przedstawione jest w postaci naśladowania dwóch odmiennych wzorców ( $\pi \alpha \rho \alpha \delta \varepsilon \dot{\gamma} \gamma \mu \alpha \tau \alpha)$ : „dwa pierwowzory w łonie bytu rzeczywistego stoją: $z$ jednej strony to, co boskie i najszczęśliwsze, a z drugiej to, co

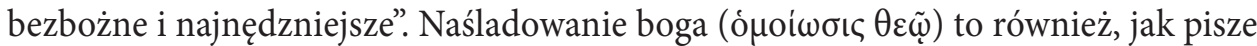
Platon, „ucieczka” ku temu co boskie i szczęściorodne. Los tych, którzy wybierają zło, opisany jest jako ruch od wzorca doskonałości do tego, co jest pierwowzorem bezbożności, przeciwieństwem tego, co boskie $(a ̊ \theta \varepsilon o v)^{28}$. Platon nawiązuje przy tym do motywu nieuchronnej kary, która spotyka nikczemnego - nie trafi on po śmierci do świata wolnego od wszelkiego zła, ale będzie obcował „tu” ze zbrodniarzami. Przeciwstawienie dwóch rzeczywistości nie jest podbudowane żadną doktryną metafizyczną, przypomina jedynie teorię idei i świata naśladowczego ${ }^{29}$.

Podobieństwo do bogów polegałoby również na naśladowaniu ich sposobu życia. Życie bogów, przynajmniej takie, jak Platon je opisuje w Fajdrosie, polega na kontemplacji idei, człowiek zatem staje się podobny bogom również poprzez poznanie intelektualne ${ }^{30}$.

23 Plato, Politia 378c-e (Witwicki, 112-113): „Jeżeli mamy jakoś ludziom wpoić to przekonanie, że między obywatelami nigdy nie ma nienawiści wzajemnej i że to jest obraza boska, to lepiej mówić to już dzieciom - niech im to mówią starcy i staruszki, a kiedy dzieci podrastają, to i poetów trzeba zmusić, żeby jakoś tak około tego swoje opowiadania układali. A jak tam syn Herę skrępował i jak ojciec rzucił Hefajstosem, kiedy ten matki chciał bronić, bo ją ojciec bił, i te walki bogów, które Homer opiewał, tych nie trzeba dopuszczać do miasta - czy tam będą pomyślane jako przenośnie, czy bez przenośni. Bo młody człowiek nie potrafi ocenić, co jest przenośnią, a co nie, a co w tym wieku weźmie w siebie jako pogląd, to się lubi przyczepiać tak, że później ani tego nie zmyjesz, ani nie przestawisz. Więc może właśnie dlatego nade wszystko o to dbać potrzeba, żeby to, co dzieciom przed wszystkim innym w uszy wpada, żeby to były mity ułożone pięknie i budująco".

24 Plato, Politia 382e (Witwicki, 120).

25 Plato, Theaetetus 176a-b (Witwicki, 80).

26 Plato, Theaetetus, 176b (Witwicki, 80).

27 Plato, Theaetetus, 176b (Witwicki, 80).

28 Plato, Theaetetus 177a (Witwicki, 81-82).

29 Por. uwagi w: Kahn, Platon, 167-168.

30 Plato, Phaedrus 249c (Regner, 33): „Pamięć bowiem w miarę możności zatapia się zawsze w tym, w czym nawet Bóg, istota boska, się zatapia. Ale właśnie jedynie mąż, który w sposób właściwy odnawia te wspomnienia i wciąż doskonałych dostępuje wtajemniczeń, staje się naprawdę doskonałym". 
Ostatecznie w Prawach Platon ukazuje Boga jako miarę wszystkiego: „A zatem bóg najbardziej mógłby być dla nas miarą wszystkich rzeczy, i to o wiele bardziej niż, jak mówią, jakiś człowiek". Jak zauważa tłumaczka fragmentu Dorota Zygmuntowicz, jest to aluzja do sformułowania Protagorasa dotyczącego zasady homo-mensura. Człowiek nie może rościć sobie pretensji do ustanawiania zasad moralnych i bycia miarą tychże zasad ${ }^{31}$. Dalej Platon precyzuje zasady etyki upodobnienia do boga:

Kto więc ma się stać takiej istocie miły, i on stać się musi taki możliwie najbardziej, przeto, wedle tej zasady, ten z nas, który jest samoopanowany, mily jest bogu, bowiem podobny, a ten, który nie jest samoopanowany, niepodobny i niezgodny, jak też niesprawiedliwy, i inne rzeczy tak samo się mają wedle tej zasady. Zrozummy wreszcie, że za tym idzie taka oto zasada, ze wszystkich, jak sądzę, najpiękniejsza i najprawdziwsza: że dla dobrego składanie ofiar i stałe obcowanie z bogami przez modły, dary ofiarne i wszelką służbę bogom jest najpiękniejsze, najlepsze i najbardziej pomocne do życia szczęśliwego, a nawet szczególnie odpowiednie, natomiast złemu człowiekowi dzieje się z natury przeciwnie do tego. Nieczysty jest bowiem na duszy człowiek zły, czysty zaś ten, kto złemu przeciwny ${ }^{32}$.

John Hare zwraca również uwagę, że w Platońskim Ionie znajdujemy obraz boga jako siły, która przyciąga ${ }^{33}$. Platon używa następującego porównania: bóg posiada siłę przyciągania, tak jak magnes, który przenosi siłę magnetyczną przez łańcuch żelaznych pierścieni. Analogicznie dusze ludzkie przedstawione są jako połączone ze sobą poprzez zachwyt, który ostateczne swe źródło znajduje w bogu. Analogia ta jest obecna również w koncepcji Arystotelesa, w której Pierwszy Nieruchomy Poruszyciel jest celem, przynajmniej o tyle, o ile jako przyczyna celowa jest przyczyną ruchu. Przy tym według Arystotelesa człowiek spełnia się w aktach rozumu, poznając najwyższe dobro, znajdując sens świata w odkryciu pierwszej przyczyny. Kontemplacja boga jest kryterium pozytywnej wartości poszczególnych wyborów życiowych danego człowieka ${ }^{34}$. Ponieważ Arystoteles w przeciwieństwie do Platona nie zaproponował żadnej szczegółowej eschatologii i ograniczył się jedynie do uznania ewentualnej nieśmiertelności (boskości) intelektu czynnego, wydaje się, że cel, którym jest kontemplacja, zamyka się w doczesnym życiu człowieka. Arystoteles w Etyce nikomachejskiej mówi co prawda o tym, że „należy, ile możności, dbać o nieśmiertelność", ale nie musi mieć na myśli przekonania o nieśmiertelności duszy po śmierci ciała. Sens tej wypowiedzi może mieć charakter całkowicie doczesny - należy dbać

31 Plato, Leges 716c (Zygmuntowicz, 232, przyp. 423).

32 Plato, Leges 716d-e (Zygmuntowicz, 232).

33 Hare, God and Morality, 15; Platon, Ion 536a (Witwicki, 17).

34 Aristoteles, Ethica eudemia 1249b (Wróblewski, 493): „Jakikolwiek wybór i posiadanie dóbr naturalnych [...] wywoła przede wszystkim kontemplację boga, ten wybór jest najlepszy, a kryterium najpiękniejsze”. 
tu i teraz o to, co charakterystyczne dla życia boskiego, czyli o życie rozumne, a nie jedynie troszczyć się o „sprawy śmiertelników”35.

W Platońskich dialogach znajdujemy zatem obraz boga, który może sankcjonować normy moralne. Jeśli czynienie dobra polega na odnajdywaniu podobieństwa do boga, w jego naśladowaniu i upodabnianiu się do niego, to bóg musi spełnić pewne warunki, aby sankcjonować moralność. Sam musi posiadać pewne atrybuty: jest dobry, sprawiedliwy, doskonały, prosty i niezmienny. Jako źródło moralności działa jako wzór. Jest jednak zależny od rzeczywistości, której nie jest twórcą (idee), nie jest również stwórcą świata materialnego. Z kolei Arystotelesowski bóg posiada również cechy doskonałościowe, jest celem, dobrem, które pociąga. Arystotelesowska Pierwsza Przyczyna jest Rozumem, posiada więc cechę bytu osobowego, ale zna jedynie siebie i żadne więzi pomiędzy nią a ludźmi nie są możliwe - bóg nie poznaje bytów zmiennych, nie jest bogiem opatrznościowym ani miłującym stwórcą, z tego też powodu dla jednostkowego człowieka może być jedynie przedmiotem kontemplacji, a nie przedmiotem aktów religijnych czy miłości. Źródłem moralności może być o tyle, o ile jest celem najlepszego działania, którym jest kontemplacja Pierwszej Przyczyny. Naśladowanie boga sprowadza się zatem ostatecznie do naśladowania jego sposobu działania, którym jest poznawanie.

\section{Bóg jako źródło moralności w poglądach św. Augustyna}

Zagadnienie relacji Boga do moralności w filozofii i teologii św. Augustyna jest samo w sobie bardzo obszerne, dlatego jego całościowe ujęcie przekracza ramy tego artykułu. Interesują mnie jedynie te aspekty jego filozofii, które odnoszą się do wyżej wymienionych koncepcji. Podejmując kwestię dotyczącą ostatecznych źródeł moralności w etyce Augustyna, skoncentruję się na pytaniu o odniesienie do greckich korzeni pewnych jego analiz w tym zakresie. Augustyn tworzy w perspektywie teizmu chrześcijańskiego, zatem można byłoby stosunkowo łatwo zinterpretować jego wizję Boga jako źródła moralności - po prostu jako prawodawcy, biorąc pod uwagę promulgowane przez Boga przykazania Starego i Nowego Testamentu. Z drugiej strony mamy w jego filozofii nawiązanie do greckiego eudajmonizmu, Augustyn uważa bowiem, że celem życia jest ostatecznie szczęście, które musi mieć charakter ponadnaturalny. Człowiek pragnie bowiem szczęścia wiecznego, które musi być nieutracalne $^{36}$. To Bóg jest ostatecznym przedmiotem pragnienia człowieka i z tego punktu widzenia koncepcja św. Augustyna pasowałaby również do pierwszej wyróżnionej przez J. Hare’a teorii tłumaczącej relację Boga do moralności. Nie odrzucając obu

35 Aristoteles, Ethica nicomachea 1177b (Gromska, 291)

36 Aurelius Augustinus, De Trinitate XIII, VII.10-11 (Stokowska, 395-397). 
tych rozwiązań, warto pokazać nieco inną perspektywę Augustyńskiej myśli, odnosząc się do (neo)platońskich elementów w jego filozofii. Jednocześnie chcę pokazać, w jaki sposób perspektywa platońska zostaje przekroczona i uzupełniona ze względu na kreacjonistyczny model relacji Bóg - świat obecny w myśli Augustyna.

Podstawą mych analiz są fragmenty 7.10-11 Wyznań, które zaczynają się wspomnieniem Augustyna dotyczącym lektury dzieł neoplatoników:

Te książki zachęcały mnie, abym wrócił do samego siebie. Zacząłem więc wchodzić w głębię mej istoty za Twoim przewodnictwem. Mogłem w nią wnikać, ponieważ Ty mnie wspomagałeś. Wszedłem tam i takim wzrokiem duchowym, jaki był mi dany, dojrzałem w górze, ponad owym wzrokiem, ponad moim umysłem światłość Boga niezmienną (lux incommutabilis) ${ }^{37}$.

Neoplatoński wątek obecny w myśli Augustyna jest w tym wypadku oczywisty. Droga do wewnątrz podmiotu, do której zachęcał Plotyn ${ }^{38}$, pozwalająca odkryć Piękno samo w sobie, zostaje wykorzystana przez Augustyna do odnalezienia Boga. O ile jednak mistyka Plotyna jest w pewnym sensie naturalna, gdyż podmiot sam dokonuje drogi ku Pięknu samemu w sobie, o tyle podmiot Augustyński jest w tym doświadczeniu wspomagany przez samego Boga. Jak trafnie zauważa John Peter Kenney, dusza nie ma wrodzonej zdolności osiągnięcia światłości Boga ani naturalnych środków, by ją osiągnąc ${ }^{39}$. W tym sensie myśl Augustyna nie jest tylko wiernym skopiowaniem tradycji neoplatonizmu. Ponadto Bóg, którego odkrywa podmiot, to Bóg Stwórca, Augustyn bowiem, opisując relację Bóg - człowiek, odnosi się do pojęcia hierarchii, która przekracza hierarchię przestrzenną. Nie tak bowiem Bóg jest nad umysłem, ,jak oliwa jest nad wodą, ani nie tak, jak niebo jest nad ziemią"40. Przykłady te ilustrują jedynie naturalny porządek rzeczy, a zachodząca między nimi relacja podporządkowania nie ma charakteru przyczynowego. W przypadku relacji Bóg - człowiek jest inaczej: Augustyn podkreśla, że Bóg jest ponad, ponieważ uczynił człowieka, a człowiek jest poniżej, ponieważ został przez Boga uczyniony ${ }^{41}$. Gradualistyczny model neoplatoński zostaje przekroczony, gdyż Bóg działa jako Stwórca

37 Aurelius Augustinus, Confessiones 7.10 (Kubiak, 149). Por. „Et inde admonitus redire ad memet ipsum, intravi in intima mea duce te, et potui, quoniam 'factus es adiutor meus'. intravi et vidi qualicumque oculo animae meae supra eundem oculum animae meae, supra mentem meam, lucem incommutabilem, non hanc vulgarem et conspicuam omni carni, nec quasi ex eodem genere grandior erat, tamquam si ista multo multoque clarius claresceret totumque occuparet magnitudine". Łacińskie wydanie Wyznań cytuję za edycją bilingwalną, zachowując jej pisownię (Augustinus, Bekenntnisse). Plotinus, Enneades 1.6.8 (Krokiewicz, 113).

Kenney, The Mysticism, 56.

40 Aurelius Augustinus, Confessiones 7.10 (Kubiak, 149). Por. „Non hoc illa erat sed aliud, aliud valde ab istis omnibus, nec ita erat supra mentem meam, sicut oleum super aquam nec sicut caelum super terram”.

41 Aurelius Augustinus, Confessiones 7.10 (Kubiak, 149): „Sed superior, quia ipsa fecit me, et ego inferior, quia factus ab ea”. 
świata, a nie jedynie jako najwyższy byt, który z konieczności dokonuje procesu emanacji. Radykalną różnicę ontyczną między stworzeniem a Bogiem Augustyn opisuje poprzez podkreślenie z jednej strony odmiennych sposobów istnienia Boga i stworzenia, a z drugiej zależności kazualnej istnienia stworzenia od Boga. Bóg istnieje w pełni (omnino esse) oraz jest niezmienny (incommutabiliter manet), stworzone rzeczy są o tyle, o ile są zależne od Boga $\mathrm{w}$ istnieniu (esse quidem, quoniam abs te sunt), w takim sensie można je nazwać nieistniejącymi, że nie istnieją tak, jak istnieje Bóg (non esse autem, quoniam id, quod es, non sunt) ${ }^{42}$.

Przywołane przez Augustyna doświadczenie obecności Boga prowadzi do zaskakujących konsekwencji. Augustyn tak je opisuje:

Wieczna Prawdo! Prawdziwa Miłości! Umiłowana Wieczności! Tyś Bogiem moim, do Ciebie wzdycham dniem i nocą. Gdy po raz pierwszy Cię poznałem, Tyś mnie do siebie przygarnął, żebym zobaczył, że powinienem coś ujrzeć, a także iż nie jestem jeszcze zdolny do ujrzenia tego. Schłostałeś słabość mego wzroku, przemożnym uderzywszy we mnie blaskiem, aż zadrżałem z miłości i zgrozy. Zrozumiałem, że jestem daleko od Ciebie w krainie, gdzie wszystko jest inaczej (regio dissimilitudinis). I zdało mi się, że słyszę Twój głos z wyżyny: „Jam pokarm dorosłych, dorośnij, a będziesz mnie pożywał; i nie wchłoniesz mnie w siebie, jak się wchłania cielesny pokarm, lecz ty się we mnie przemienisz". Zrozumiałem tė̇, że za niegodziwość ukarałeś człowieka i sprawiłeś, że się rozprzęgła, jak pajęczyna, dusza moja ${ }^{43}$.

Otrzymujemy opis doświadczenia człowieka, który uświadamia sobie swój stan egzystencjalny. Jest w krainie, gdzie „wszystko jest inaczej” - regio dissimilitudinis, dosłownie $\mathrm{w}$ „krainie niepodobieństwa”. Jedna $\mathrm{z}$ możliwych interpretacji tego fragmentu zmierza do stwierdzenia, że podmiot doświadcza absolutnej niewspółmierności swojego stanu ontycznego w stosunku do Boga. Człowiek jako byt stworzony jest

42 Aurelius Augustinus, Confessiones 7.11: „Et inspexi cetera infra te et vidi nec omnino esse nec omnino non esse: esse quidem, quoniam abs te sunt, non esse autem, quoniam id, quod es, non sunt. id enim vere est, quod incommutabiliter manet".

43 Aurelius Augustinus, Confessiones 7.10 (Kubiak, 150). Por. „O aeterna veritas et vera caritas et cara aeternitas! tu es deus meus, tibi suspiro die ac nocte. et cum te primum cognovi, tu adsumpsisti me, ut viderem esse, quod viderem, et nondum me esse, qui viderem. et reverberasti infirmitatem aspectus mei, radians in me vehementer, et contremui amore et horrore: et inveni longe me esse a te in regione dissimilitudinis, tamquam audirem vocem tuam de excelso: cibus sum grandium: cresce et manducabis me. nec tu me in te mutabis sicut cibum carnis tuae, sed tu mutaberis in me. et cognovi, quoniam pro iniquitate erudisti hominem, et tabescere fecisti sicut araneam animam meam". W tłumaczeniu Zygmunta Kubiaka nie znajdujemy informacji, że ostanie zdanie nawiązuje do jednego z psalmów Ps 38(39),12. Ostatnia część tekstu Augustyna jest pokrewna z wersją łacińską Psalmu $38 \mathrm{z}$ Wulgaty („A fortitudine manus tuæ ego defeci/ in increpationibus propter iniquitatem corripuisti hominem/ et tabescere fecisti sicut araneam animam eius", Ps 38,12, Biblia Sacra, 816), choć Augustyn najprawdopodobniej korzystał z wcześniejszego tłumaczenia Pisma Świętego na łacinę, tzw. wersji Vetus Latina: „propter iniquitatem erudisti hominem/ et tabescere fecisti sicut aranea animam ejus" (por. Bibliorum Sacrorum Latinae versiones antiquae, seu Vetus Italica, II, pars I, 80). Jak widać fragment z obecny w Wyznaniach nie jest dosłownym cytatem z żadnej z wersji psalmu. 
radykalnie odmienny od Boga, doświadcza swojej kontyngencji i zmienności w opozycji do trwającego, niezmiennego bytu Bożego. Przytoczony wcześniej fragment 7.11 Wyznań potwierdzałby taką interpretację. Kraina niepodobieństwa to w tym wypadku kraina doświadczenia przez człowieka własnego statusu egzystencjalnego. Dopiero doświadczenie udzielone przez Boga, a zatem doświadczenie ponadnaturalne, daje człowiekowi możliwość faktycznego dostrzeżenia tego statusu. Dodatkowo pojawia się obietnica przemiany, którą ofiarowuje Bóg, przekraczająca naturalny bieg rzeczy. Dusza budzi się na skutek boskiej interwencji. Następuje deifikacja, która przekracza neoplatoński schemat wniknięcia duszy w samą siebie w celu odkrycia prawdy, przemiana bowiem jest ostatecznie możliwa dzięki Wcielonemu Bogu, uczestnictwu w Ciele Chrystusa. Obraz spożywania pokarmu jest jawną analogią do Eucharystii ${ }^{44}$.

Język, którego użył Augustyn do opisania swojego wewnętrznego doświadczenia, jest zakorzeniony w platonizmie i neoplatonizmie. Źródeł wyrażenia „regio dissimilitudinis" historycy doszukują się bowiem w Platońskim micie o dwóch cyklach świata, zawartym w dialogu Polityk ${ }^{45}$. Pojawia się w nim sformułowanie „apeiron niepo-

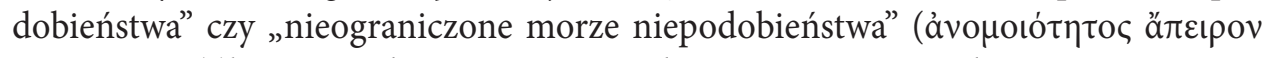

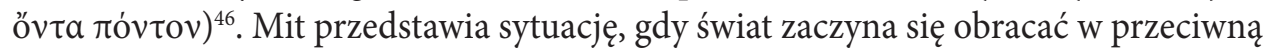
stronę. Przyczyną tego jest fakt, że dwie zasady, z których bóg złożył świat - element tożsamy oraz element różny - przed utworzeniem kosmosu istniały osobno. Platon przeciwstawia bezład i boga oraz naturę cielesną i rozum, używając takich wyrażeń dla bezładu, jak: „dawna dysharmonia”, „apeiron niepodobieństwa”, bycie inne niż „według tego samego i stale w ten sam sposób”. Ze względu na obecność nierozumnej zasady harmonia świata może zostać zaburzona, wszystko zostaje odwrócone i jeśli bóg nie podejmie interwencji, zwycięży bezład i żądza ${ }^{47}$. W przekonaniu Eugène’a TeSellego Augustyn podąża w Wyznaniach za platońską tradycją, dostrzegając, że u korzeni wszystkich rzeczy leży przygodność i omylnośćc ${ }^{48}$. Potwierdzałoby to zatem ontologiczną interpretację regio dissimilitudinis jako odpowiednika platońskiej krainy niepodobieństwa. Jak jednak zauważa Taylor, jest wysoce nieprawdopodobne, aby Augustyn czytał Polityka ${ }^{49}$. Podobne wyrażenie pojawia się jednak w Enneadach Plotyna:

Powiedzieliśmy zaś, że cnota nie jest pięknem samym ani samym dobrem, ponieważ „samo-piękno" i „samo-dobro" jest przed nią i ponad nią, a ona staje się tylko w pewien spo-

Zob. uwagi w: McGinn, The Presence of God, 251.

Warto w tym miejscu przywołać następujące prace: Taylor, „Regio dissimilitudinis”, 305-306; Gilson, „Regio dissimilitudinis”, 108-130; Courcelle, „Tradition Neo-Platonicienne”, 5-33; TeSelle, „Regio Dissimilitudinis", 153-179.

Plato, Politicus 273d6 (Witwicki, 26).

Zygmuntowicz, „O Platońskiej”, 149-151.

TeSelle, „Looking for Home”, 117.

Taylor, „Regio dissimilitudinis”, 305. 
sób dobrem i pięknem przez udział. Jak więc idąc od cnoty w górę znajdzie się piękno i dobro, tak i schodząc w dół od złości znajdzie się „samo-zło”: kto zaczął od złości, ten ma, powiedzmy, „widzenie” samego zła, jeżeli tylko patrzy, a już współudział, jeżeli w nie

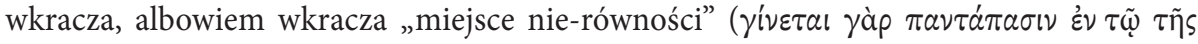

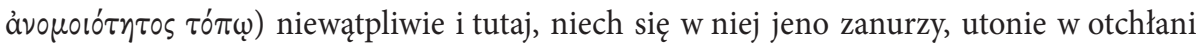
mrocznego błota $(\beta o ́ p \beta o p o s)^{50}$.

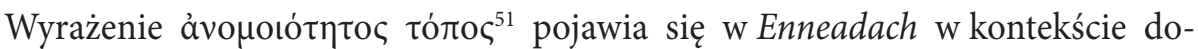
świadczenia zła. Plotyn poprzez obraz wstępowania i zstępowania duszy ilustruje schemat gradualistycznej rzeczywistości: od najwyższego Dobra, poprzez dobro częściowe, którym jest cnota, aż do poznania zła i złego działania. Uczestnictwo w złu jest zobrazowane uczestnictwem w tym, co platońskim językiem Plotyn określa regionem niepodobieństwa, odmienności. Platońskim wyrażeniem jest również termin ßó $\beta$ $\rho \circ$, nawiązujący do fragmentu z Fedona (69c), w którym Platon używa tego słowa do opisu nędznego życia tych, którzy nie dbali o cnoty i poznanie prawdy.

Do koncepcji krainy niepodobieństwa z Polityka Plotyn wprowadza element wyraźnie aksjologiczny. Ten aspekt jest szczególnie ważny dla Augustyńskiej koncepcji regio dissimilitudinis. Doświadczenie bycia w krainie niepodobieństwa ma zgodnie z fragmentem z Wyznań również charakter aksjologiczny i moralny. Niepodobieństwo wynika nie tylko ze stanu przygodności, zmienności, bycia w tym świecie materialnym, ale ze stanu grzechu. Augustyn pisze bowiem w dalszej części tekstu, że ze względu na niegodziwości (pro iniquitate) została „zniszczona jak pajęczyna” jego dusza. Moralne zło zatem jest powodem znalezienia się w krainie niepodobieństwa do Boga, a dusza znajduje się na granicy istnienia (prawie znika, tak jak znika pajęczyna). W takiej interpretacji znajdujemy obraz istoty ludzkiej, która czyniąc zło, oddala się coraz bardziej od obrazu - wzorca, który ma naśladować. W tekście Augustyna znajdujemy zatem bardzo podobną intuicję, jak u Platona - o Bogu jako źródle moralności, który stanowi wzorzec. Nie jest to jedynie wzorzec doskonałego charakteru. Między bogami a duszą ludzką u Platona zachodzi bowiem tylko różnica stopnia. Ilustrację tego znajdujemy choćby w Fajdrosie - dusza uporządkowana jest jak bóg, może naśladować jego życie, kontemplując idee. Bóg Augustyna to wzorzec będący Stwórcą, który stwarza człowieka na swoje podobieństwo. To uzupełnia, ale i przekracza intuicje platońskie, gdyż w św. Augustyna ontologii zła każdy akt zła moralnego dokonany przez człowieka jest nie tylko sprzeciwem wobec miary, ale i przeciwstawieniem się stwórczemu działaniu Boga wobec człowieka.

50 Plotinus, Enneades 1.8.13 (Krokiewicz, 135-136).

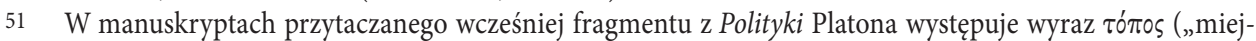

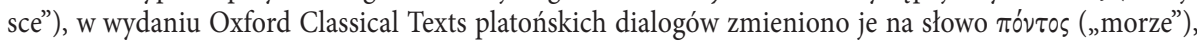
postępując za interwencją Proklosa. Plotyn odczytywał to słowo jako „miejsce”, stąd tak też będzie ono funkcjonowało w Enneadach. Zob. Kalligas, The Enneads, 238. 
Wszystkie aspekty koncepcji Boga jako źródła moralności według J. Hare’a Boga jako tego, który jest przedmiotem pragnienia, Boga jako kogoś, kto kocha, Boga jako suwerena (legislatora) oraz Boga jako wzorca - można odnaleźć również w poglądach Augustyna. Przede wszystkim jednak Bóg jest źródłem moralności jako istota stwórcza, jest Bogiem, który stwarza istoty do Niego podobne. Odwrócenie się poprzez zło moralne sprawcy od Boga (Najwyższego Dobra, które jest stwórcze) jest załamaniem ontologicznego porządku. W efekcie pojawia się doświadczenie niepodobieństwa tak głębokiego, że graniczy ono z nicością. Czynienie zła jest odwracaniem się od źródła, jest unicestwianiem. Bóg jest pierwotnie źródłem moralności jako stwórczy wzorzec, a wtórnie jako dawca nakazów i zakazów czy źródło szczęścia.

\section{Wnioski}

Przekonanie o istnieniu związku Boga/bogów z moralnością było obecne zarówno w greckiej religii, jak i filozofii. Bogowie greckiej religii ludowej mogli ugruntowywać moralność poprzez system kar, których powinien się spodziewać sprawca za swoje czyny. Bycie gwarantem moralności nie wymagało od nich posiadania wzorcowego charakteru moralnego. Zmiana tego zjawiska ma miejsce w epoce sokratejskiej. Bóg/bogowie Sokratesa, Platona czy Arystotelesa nabierają cech doskonałościowych i to sankcjonuje ich moc kształtowania moralności. W ramach tych koncepcji rodzi się idea upodobnienia się do Boga/bogów i naśladowania wzorca charakterologicznego poprzez wykonywanie działań, które wykonuje Bóg (poznawanie), oraz dbanie o cnotę. Bóg, zwłaszcza filozoficzny, jest traktowany również jako cel oraz przedmiot uszczęśliwiający. W koncepcji św. Augustyna Bóg jest prawodawcą oraz uszczęśliwiającym celem ostatecznym, jako najwyższe Dobro jest jednocześnie doskonały. Jednak kreacjonistyczny model relacji Bóg - świat obecny w myśli Augustyna ukazuje jego koncepcję Boga jako źródła moralności jako uzupełnienie modeli wyróżnionych przez J. Harea. Dlatego, że Bóg stwarza istoty do Niego podobne, jest On źródłem moralności nie tylko jako wzorzec charakterologiczny, ale przede wszystkim jako istota stwórcza, stwarzająca na swój obraz. Zło moralne jest odwróceniem się sprawcy od Boga i załamaniem ontologicznego porządku. Doświadczenie owego załamania może być udziałem osób, które na skutek Bożej interwencji mogą uświadomić sobie swój egzystencjalny status istnienia w „krainie niepodobieństwa”. Kreacjonistyczna i aktywna rola Boga w relacji do człowieka przekracza w sposób istotny model neoplatoński, choć św. Augustyn używa języka obecnego w tym modelu. 


\section{Bibliografia}

Aristoteles, Ethica eudemia, tł. pol. W. Wróblewski: Arystoteles, Etyka eudemejska (Arystoteles Dzieła Wszystkie 5; Warszawa: Wydawnictwo Naukowe PWN 1996).

Aristoteles, Ethica nicomachea, tł. pol. D. Gromska: Arystoteles, Etyka nikomachejska (Arystoteles Dzieła Wszystkie 5; Warszawa: Wydawnictwo Naukowe PWN 1996).

Aurelius Augustinus, Confessiones, tł. niem. W. Thimme: Augustinus, Bekenntnisse (Düsseldorf - Zürich: Artemis \& Winkler 2004).

Aurelius Augustinus, Confessiones, tł. pol. Z. Kubiak: Św. Augustyn, Wyznania (Kraków: Znak 1987).

Aurelius Augustinus, De trinitate, tł. pol. M. Stokowska: Św. Augustyn, O Trójcy Świętej (Kraków: Znak 1996).

Biblia Sacra iuxta vulgatam versionem (red. R. Weber - R. Gryson) (Stuttgart: Deutsche Bibelgesellschaft 2007).

Bibliorum Sacrorum Latinae versiones antiquae, seu Vetus Italica (red. P. Sabatier) (Parisiis: Apud Franciscum Didot 1751) II/1.

Courcelle, P., „Tradition Neo-Platonicienne et Traditions Chretiennes de la region de Dissemblance (Platon, Politique, 273d)", Archives d'histoire doctrinale et littéraire du Moyen Age 24 (1957) 5-33.

Eliade, M., Historia wierzeń i idei religijnych. I. Od epoki kamiennej do misteriów eleuzyńskich (Warszawa: Pax 1988).

Euripides, Bellerophon, tł. pol. J. Łanowski: Eurypides, „Bellerofont”, Tragedie (Warszawa: Państwowy Instytut Wydawniczy 1980).

Gilson, E., „Regio dissimilitudinis de Platon a saint Bernard de Clairvaux”, Mediaeval Studies 9/1 (1947) 108-130.

Hare, J., God and Morality. A Philosophical History (Chichester: Blackwell 2007).

Herbut, J., „Religia”, Leksykon filozofii klasycznej (red. J. Herbut) (Lublin: TN KUL 1997) 466.

Heubeck A., „Introduction to Homer's Odyssey”, A Commentary on Homer's Odyssey (A. Heubeck - S. West - J.B. Hainsworth) (Oxford: Clarendon Press 1988) 22-23.

Jaeger, W., Teologia wczesnych filozofów greckich (Kraków: Homini 2007).

Kahn, C.H., Platon i dialog postsokratyczny (Warszawa: Teologia Polityczna 2021).

Kalligas, P., The Enneads of Plotinus. A Commentary (Princeton, NJ - Oxford: Princeton University Press 2014) I.

Kenney, J.P., The Mysticism of Saint Augustin. Re-Reading the Confessions (New York: Routledge 2005).

Legutko, R., Filozofia presokratyków. Od Talesa do Demokryta (Kraków: Ośrodek Myśli Politycznej 2020).

Legutko, R., Sokrates. Filozofia męża sprawiedliwego (Poznań: Zysk i S-ka 2013).

Lloyd-Jones, H., The Justice of Zeus (Berkeley, CA: California University Press 1971).

McGinn, B., The Presence of God. A History of Western Christian Mysticism. I. The Foundations of Mysticism (New York: Crossroad 1991).

Mikalson, J.D., Greek Popular Religion in Greek Philosophy (Oxford: Oxford University Press 2010).

Plato, Apologia Socratis, tł. pol. W. Witwicki: Platon, Obrona Sokratesa (Warszawa: PWN 1982). 
Plato, Euthyphron, tł. pol. W. Witwicki: Platon, Eutyfron (Warszawa: PWN 1982).

Plato, Ion, tł. pol. W. Witwicki: Platon, Ion (Kęty: Wydawnictwo Derewiecki 2021).

Plato, Leges, tł. pol. D. Zygmuntowicz: Platon, Prawa (Kęty: Derewiecki 2017).

Plato, Phaedrus, tł. pol. L. Regner: Platon, Fajdros (Warszawa: Wydawnictwo Naukowe PWN 1993).

Plato, Politia, tł. pol. W. Witwicki: Platon, Państwo (Warszawa: Wydawnictwo AKME 1991).

Plato, Politicus, tł. pol. W. Witwicki: Platon, Polityk (Kęty: Derewiecki 2021).

Plato, Theaetetus, tł. pol. W. Witwicki: Platon, Teajtet (Warszawa: PWN 1959).

Plotinus, Enneades, tł. pol. A. Krokiewicz: Plotyn, Enneady (Warszawa: PWN 1959) I.

Plotinus, Plotini Opera. I. Porphyrii vita Plotini. Enneades I-III (red. P. Henry - H.-R. Schwyzer) (Oxonii: Clarendon 1964).

Reale, G., Historia filozofii starożytnej. I. Od początków do Sokratesa (Lublin: Redakcja Wydawnictw KUL 1993).

Taylor, A.E., „Regio dissimilitudinis”, Archives d'histoire doctrinale et littéraire du Moyen Age 9 (1934) 305-306.

TeSelle, E., „'Regio Dissimilitudinis' in the Christian Tradition and its Context in Late Greek Philosophy”, Augustinian Studies 6 (1975) 153-179.

TeSelle, E., „Looking for Home: Travel As Metaphor in Augustine”, Annali d'italianistica 14 (1996) 103-120.

Zygmuntowicz, D., „O Platońskiej i Nietzscheańskiej wiedzy tragicznej”, Przegląd Filozoficzny Nowa Seria 14/3 (2005) 145-158. 